\title{
ANALISIS PENERAPAN PEMBIAYAAN MURABAHAH BERDASARKAN PESANAN DAN TANPA PESANAN SERTA KESESUAIAN DENGAN PSAK 102
}

\author{
Muhammad Yusuf \\ Accounting and Finance Department, Faculty of Economics and Communication, BINUS University \\ Jln. K. H. Syahdan No. 9, Palmerah, Jakarta Barat 11480 \\ yusuf_moch2002@yahoo.com
}

\begin{abstract}
The development of banking industries in Indonesia is followed by many Islamic banks popping up that offer different products with existing products in the conventional banking products: murabahah which is the flagship product of Islamic banks so that the proportion is the most dominating product among other products. Murabahah is a sale and purchase agreement with the selling price of goods at cost plus an agreed profit which the seller must disclose the cost of the goods to the buyer. This study aims to investigate the implementation of Murabahah financing at Syariat Bank X and to know the accounting treatment of murabahah in Syariat Bank X and compliance with PSAK 102. The research problem is how the application and the accounting treatment of Murabahah in Bank Syariat X year 2010 - 2011 and compliance with PSAK 102. This study used qualitative approach to the secondary data collection methods and interviews with Syariat Bank X management. The results of the study showed that in terms of the accounting treatment of Murabahah transactions, the accounting treatment of Murabahah in Syariat Bank X is not in accordance with PSAK 102 on Accounting for Murabahah Syariat Bank X in implementing orders only apply where an order only, whereas PSAK 102, murabahah can be done with/without any order. And in the case of disclosure of accounting murabahah, there is a lack of Syariat Bank $X$ from the seller or the bank without the express terms of the purchaser. Based on this research, Syariat Bank $X$ should complete in terms of disclosure of accounting disclosure Murabahah which explains in terms of the buyer and implementing murabahah without orders in accordance with PSAK 102.
\end{abstract}

Keywords: murabahah financing, recording and disclosure of Accounting for Murabahah, PSAK 102

\begin{abstract}
ABSTRAK
Perkembangan industri perbankan di Indonesia diikuti dengan bermunculannya bank syariat yang menawarkan produk berbeda dengan produk perbankan konvensional, antara lain produk murabahah yang merupakan produk andalan dari bank syariat sehingga proporsinya paling mendominasi di antara produk lainnya. Murabahah adalah akad jual beli barang dengan harga jual sebesar biaya perolehan ditambah keuntungan yang disepakati yang di dalamnya penjual harus mengungkapkan biaya perolehan barang kepada pembeli. Penelitian ini bertujuan untuk mengetahui pelaksanaan pembiayaan murabahah pada Bank Syariat $X$ serta mengetahui perlakuan akuntansi Murabahah Bank Syariat X dan kesesuaiannya dengan PSAK 102. Masalah penelitian ini adalah bagaimana penerapan dan perlakuan akuntansi Murabahah pada Bank Syariat X Tahun 2010-2011 dan kesesuaiannya dengan PSAK 102. Penelitian ini menggunakan pendekatan kualitatif, dengan data yang diperoleh berupa data sekunder, serta wawancara dengan manajemen Bank Syariat X. Hasil penelitian menunjukkan bahwa dalam hal perlakuan akuntansi atas transaksi Murabahah pada Bank Syariat X sudah sesuai dengan PSAK 102 tentang Akuntansi murabahah, namun dalam mengimplementasikan pembiayaan murabahah, hanya berdasarkan pesanan saja, sedangkan pada PSAK No. 102 murabahah dapat dilakukan berdasarkan atau tanpa pesanan. Dalam hal pengungkapan akuntansi Murabahah, Bank Syariat X masih terdapat kekurangan karena hanya mengungkapkan dari sisi penjual atau pihak bank, tanpa mengungkapkan dari sisi pembeli. Sebaiknya Bank Syariat X melengkapi dalam hal pengungkapan akuntansi murabahah, yaitu menjelaskan pengungkapan dari sisi pembeli dan penjual, serta menerapkan murabahah berdasarkan tanpa pesanan sesuai dengan PSAK No. 102.
\end{abstract}

Kata kunci: pembiayaan murabahah, pencatatan dan pengungkapan akuntansi murabahah, PSAK 102 


\section{PENDAHULUAN}

Berdasarkan perkembangan peraturan perbankan yang terakhir, Bank Indonesia akhirnya menerbitkan undang-undang yang lebih spesifik menjelaskan tentang perbankan syariat yaitu undangundang No. 21 Tahun 2008. Undang-undang ini menjadikan perbankan syariat sebagai landasan hukum yang jelas dari sisi kelembagaan dan sistem operasional. Kehadiran undang-undang ini memicu peluang yang lebih besar yang diberikan kepada masyarakat untuk mendapatkan pelayanan perbankan sepenuhnya yang sesuai dengan syariat Islam. Salah satunya adalah perbankan syariat menawarkan transaksi yang tidak berlandaskan pada konsep bunga, diharapkan dapat lebih optimal melayani kalangan masyarakat yang belum dapat tersentuh oleh perbankan konvensional dan memberikan pembiayaan dalam pengembangan usaha berdasarkan sistem syariat Islam.

Perbankan syariat menjalankan sistem operasionalnya dengan memberlakukan sistem bagi hasil (profit and lost sharing) dan berbagi risiko (risk sharing) dengan nasabahnya yang memberikan penjelasan atas setiap perhitungan keuangan atas transaksi yang dilakukan sehingga akan meminimalkan kegiatan spekulatif dan tidak produktif. Dalam ajaran Islam, sebuah transaksi yang melibatkan dua orang antara pembeli dan penjual tidak boleh ada yang merasa dirugikan. Keduanya harus dapat saling bekerja sama dan melakukan transaksi sesuai dengan kesepakatan yang menandakan bahwa tidak ada salah satu pihak yang merasa dirugikan karena kesepakatan tersebut merupakan sebuah akad (perjanjian) yang telah disetujui bersama.

Data Bank Indonesia menunjukkan bahwa di Indonesia per September 2011 terdapat Bank Umum Syariat 11 (BUS), 23 Unit Usaha Syariat (UUS), dan 154 BPRS. Berikut tabel berdasarkan hasil statistik Bank Indonesia.

Tabel 1 Data Bank Syariat di Indonesia Tahun 2006 s/d September 2011

\begin{tabular}{|c|c|c|c|c|c|c|}
\hline \multicolumn{7}{|c|}{ Data Jaringan kantor Perbankan Syariat } \\
\hline Tahun & 2006 & 2007 & 2008 & 2009 & 2010 & $\begin{array}{l}\text { Sept } \\
2011\end{array}$ \\
\hline Bank Umum Syariat & 3 & 3 & 5 & 6 & 11 & 11 \\
\hline Unit Usaha Syariat & 20 & 26 & 27 & 25 & 23 & 23 \\
\hline BPRS & 105 & 114 & 131 & 138 & 150 & 154 \\
\hline
\end{tabular}

Sumber: Data Statistik Bank Indonesia, September 2011

Sehubungan dengan hal tersebut, dikeluarkan Undang-Undang No.10 Tahun 1998. Dalam hal ini Bank Indonesia selaku regulator keuangan memberikan kesempatan kepada lembaga keuangan yaitu, Bank Indonesia untuk memutuskan dan melakukan percepatan perbankan syariat. Hal ini dibuktikan dengan diperbolehkan bahkan dianjurkan bank konvensional untuk membuka unit usaha syariat (bank konvensional yang membuka cabang syariat). Bank Indonesia sebagai lembaga pengawas dan Pembina perbankan di Indonesia memberikan dorongan untuk tumbuhnya industri bank yang sehat dan berkelanjutan, di antaranya adalah dengan memperkuat bargaining bank di dunia perbankan melalui program penguatan industri perbankan yang dikenal dengan Asosiasi Perbankan Indonesia (API). Berdasarkan sisi perusahaan yaitu kemampuan dan efektivitas kinerja perusahaan terutama yang berhubungan dengan finansial dan tingkat kesehatan bank, sedangkan dari sisi operasional usaha yaitu kemampuan menjaga kepercayaan nasabah serta kemampuan pengelolaan.

Berdasarkan data yang dikeluarkan Bank Indonesia ditunjukkan bahwa produk pembiayaan yang disalurkan oleh bank syariat masih tinggi peminatnya di kalangan masyarakat. Hal ini terbukti 
dari tujuh tahun terakhir jumlah angka pembiayaan terus meningkat. Produk pembiayaan yang sangat diminati adalah murabahah yakni mencapai sekitar 46,161 miliar pada Juni 2012, dan yang kedua adalah produk pembiayaan musyarakah yakni mencapai sekitar 16,295 miliyar pada Juni 2012.

Tabel 2 Komposisi Pembiayaan yang Diberikan Bank Syariat

(Dalam Miliar Rupiah)

\begin{tabular}{lcccccccc}
\hline \multicolumn{1}{c}{ Akad } & $\mathbf{2 0 0 5}$ & $\mathbf{2 0 0 6}$ & $\mathbf{2 0 0 7}$ & $\mathbf{2 0 0 8}$ & $\mathbf{2 0 0 9}$ & $\mathbf{2 0 1 0}$ & $\mathbf{2 0 1 1}$ & $\begin{array}{c}\mathbf{2 0 1 2} \\
\text { (juni) }\end{array}$ \\
\hline Mudharabah & 3,124 & 4,062 & 5,578 & 6,205 & 6,597 & 8,631 & 10,229 & 9,549 \\
Musyarakah & 1,898 & 2,335 & 4,406 & 7,411 & 10,412 & 14,624 & 18,960 & 16,295 \\
Murabahah & 9,487 & 12,624 & 16,553 & 22,486 & 26,321 & 37,508 & 56,365 & 46,161 \\
Salam & 0 & 0 & 0 & 0 & 0 & 0 & 0 & 0 \\
Istishna & 282 & 337 & 351 & 369 & 423 & 347 & 326 & 322 \\
Ijarah & 316 & 836 & 516 & 765 & 1,305 & 2,341 & 3,839 & 2,927 \\
Qard & 125 & 250 & 540 & 959 & 1,829 & 4,731 & 12,937 & 7,362 \\
\hline Total & $\mathbf{1 5 , 2 3 3}$ & $\mathbf{2 0 , 4 4 5}$ & $\mathbf{2 7 , 9 4 4}$ & $\mathbf{3 8 , 1 9 5}$ & $\mathbf{4 6 , 8 8 6}$ & $\mathbf{6 8 , 1 8 1}$ & $\mathbf{1 0 2 , 6 5 5}$ & $\mathbf{8 2 , 6 1 6}$ \\
\hline
\end{tabular}

Sumber: Statistik Perbankan Syari’ah Bank Indonesia

Secara umum efektivitas fungsi intermediasi perbankan syari'ah tetap terjaga seiring pertumbuhan dana yang dihimpun maupun pembiayaan yang relatif tinggi dibandingkan perbankan nasional, serta penyediaan akses jaringan yang meningkat dan menjangkau kebutuhan masyarakat secara lebih luas sehingga masih memiliki fundamental yang cukup kuat untuk memanfaatkan potensi membaiknya perekonomian nasional.

Bank dianggap mampu memfokuskan dirinya dan memberikan kontribusi aktif dalam penyaluran dana pada masyarakat. Peluang yang diberikan pemerintah kepada bank tersebut, membuka kesempatan bagi bank untuk mempertahankan eksistensinya dengan cara meningkatkan besarnya keuntungan yang diperoleh, ataupun dengan cara memperkecil biaya operasional sehingga dapat melakukan efisiensi usaha. Besarnya keuntungan yang diperoleh dan kecilnya biaya operasional pemasaran merupakan salah satu faktor penting untuk membawa perusahaan pada posisi persaingan yang semakin kuat, agar mampu bertahan dan mampu meningkatkan usahanya, sehingga mendapatkan keuntungan yang sesuai dengan yang diinginkan. Hal ini dilakukan oleh perbankan di Indonesia, salah satunya adalah Bank Syariat X.

Bank Syariat X merupakan salah satu bank syariat di Indonesia, yang menjalankan konsep murabahah yaitu akad jual beli barang, dengan menyatakan harga perolehan dan keuntungan (margin) yang disepakati oleh penjual dan pembeli. Bank Syariat X memberikan pelayanan pembiayaan murabahah, yang berupa pembiayaan investasi, pembiayaan modal kerja, dan pembiayaan konsumtif. Salah satu pembiayaan konsumtif adalah untuk pembiayaan kepemilikan kendaraan bermotor, kavling atau untuk renovasi rumah. Selama masa pembiayaan, besarnya angsuran tetap dan tidak berubah sampai lunas. Bank Syariat $\mathrm{X}$ memberikan pembiayaan dalam bentuk pembayaran secara kredit/cicilan dan mempunyai beberapa sistem, prosedur dan persyaratan yang harus dipenuhi oleh calon penerima pembiayaan.

Latar belakang peneliti sebelumnya tentang akuntansi Murabahah, di antaranya yaitu penelitian yang dilakukan oleh Kusmiyati (2007). Berdasarkan analisis yang telah dilaksanakan, terlihat bahwa sebagian besar konsep dan pelaksanaan pembiayaan murabahah pada BMT telah sesuai dengan prinsip-prinsip syariat. Berdasarkan latar belakang tersebut, dalam penelitian penelitian ini akan dibahas mengenai pembiayaan murabahah yang dilakukan oleh Bank Syariat X dengan judul “Analisis Penerapan Pembiayaan Murabahah Berdasarkan Pesanan dan Tanpa Pesanan Serta Kesesuaian dengan Psak 102”. 


\section{Rumusan Masalah}

Rumusan masalah pada penelitian ini adalah: a) Bagaimana penerapan dan perlakuan akuntansi murabahah berdasarkan pesanan dan tanpa pesanan pada Bank Syariat X? Dan b) bagaimana perlakuan akuntansi murabahah pada Bank Syariat X dan kesesuaiannya dengan PSAK 102 ?

\section{Tujuan dan Manfaat Penelitian}

Sedangkan tujuan dan manfaat penelitian ini adalah pertama untuk mengetahui dan menganalisis pelaksanaan murabahah berdasarkan pesanan dan tanpa pesanan pada Bank Syariat X. Kedua, mengetahui perlakuan dan menganalisis akuntansi murabahah Bank Syariat $\mathrm{X}$ dan kesesuaiannya dengan PSAK 102.

\section{Kajian Pustaka}

Istilah yang digunakan untuk sebutan Bank Syariat adalah Bank Islam. Secara akademik, istilah Syariat dan Islam mempunyai pengertian yang berbeda, namun secara teknis untuk penyebutan Bank Syariat dan Bank Islam adalah sama. Dalam undang-undang nomor 21 tahun 2008 pasal 1 pengertian perbankan syariat adalah sebagai berikut:

Perbankan syariah adalah segala sesuatu yang menyangkut tentang Bank Syariah dan Unit Usaha Syariah, mencakup kelembagaan, kegiatan usaha, serta cara dan proses dalam melaksanakan kegiatan usahanya.

Berdasarkan rumusan tersebut, perbankan syariat adalah perbankan yang beroperasi sesuai dengan prinsip-prinsip syariat Islam yaitu tata cara beroperasinya sesuai dengan Alquran dan Hadist, khususnya yang menyangkut tata cara bermuamalat. Tata cara bermuamalat mengatur hubungan antara bank dengan pihak lain dalam rangka penghimpunan dan penyaluran dana, serta kegiatan perbankan syariat yang lainnya.

Berdasarkan Undang-undang nomor 10 tahun 1998 pasal 1 butir 13:

Prinsip syariah adalah aturan perjanjian berdasarkan hukum Islam antara bank dan pihak lain untuk penyimpanan dana dan atau pembiayaan kegiatan usaha, atau kegiatan lainnya yang dinyatakan sesuai dengan syariah, antara lain pembiayaan berdasarkan prinsip bagi hasil (mudharabah), pembiayaan berdasarkan prinsip penertaan modal (musyarakah), prinsip jual beli barang dengan memperoleh keuntungan (murabahah),.....

Dalam penyaluran dana bank syariat dapat mempergunakan prinsip jual beli yang terdiri dari Murabahah, Salam dan salam Paralel, Istishna dan Istishna Paralel, dapat juga mempergunakan prinsip bagi hasil yang terdiri dari pembiyaan mudharabah dan pembiayaan musyarakah dan dapat juga dengan prinsip ujroh yaitu Ijarah dan Ijarah Mutahia Bittamlik.

Pengertian penyaluran dana meliputi pola jual beli yang dibukukan dalam perkiraan piutang, pola bagi hasil yang dibukukan dalam pembiayaan dan pola ujroh untuk Ijarah yang dibukukan dalam Aktiva Ijarah, sehingga sangat jelas pembiayaan merupakan bagian dari penyaluran dana yang dilakukan oleh bank syariat dan tidak tepat apabila kredit pada bank konvensional diterjemahkan sama dengan pembiayaan pada bank syariat, pembiayaan merupakan sebagian dari penyaluran dana. 


\title{
Pengertian Murabahah
}

Menurut PSAK 102 Akuntansi Murabahah, paragraf 5, dinyatakan bahwa :

Murabahah akad jual beli barang dengan harga jual sebesar biaya perolehan ditambah keuntungan yang disepakati dan penjual harus mengungkapkan biaya perolehan barang tersebut kepada pembeli.

Adapun pengertian murabahah menurut Rivai dan Veithzal (2008: 145) adalah :

Akad jual beli atas suatu barang, dengan harga yang disepakati antara penjual dan pembeli, setelah sebelumnya penjual menyebutkan dengan sebenarnya harga perolehan atas barang tersebut dan besarnya keuntungan yang diperolehnya.

\section{Jenis-jenis Murabahah}

Murabahah sesuai jenisnya dapat dikategorikan dalam: murabahah tanpa pesanan, artinya ada yang beli atau tidak, bank syariat menyediakan barang. Dan murabahah berdasarkan pesanan, artinya bank syariat baru akan melakukan transaksi jual beli apabila ada pesanan. Murabahah berdasarkan pesanan dapat dikategorikan dalam sifat yang mengikat, artinya murabahah berdasarkan pesanan tersebut mengikat untuk dibeli oleh nasabah sebagai pemesan; dan sifat yang tidak mengikat artinya walaupun nasabah telah melakukan pemesanan barang, namun nasabah tidak terikat untuk membeli barang tersebut.

Dari cara pembayaran murabahah dapat dikategorikan menjadi pembayaran tunai dan pembayaran tangguh. Dalam praktik yang dilakukan oleh bank syariat saat ini adalah Murabahah berdasarkan pesanan, sifatnya mengikat dengan cara pembayaran tangguh.

\section{Akuntansi Murabahah berdasarkan PSAK 102}

\section{Pada saat memberikan kuasa ke nasabah}

Bank memberi kuasa kepada nasabah untuk membeli barang, maka hal ini dibukukan dalam perkiraan piutang wakalah sebesar uang yang diserahkan kepada nasabah, sedangkan apabila barangnya telah ada dan telah diserahkan kepada nasabah, baru dibukukan dalam perkiraan piutang murabahah. Pencatatan akuntansi yang dikeluarkan oleh PSAK 102, maka transaksi dicatat sebagai berikut:

\author{
Dr. Piutang Wakalah \\ Cr. Kas/ rekening nasabah
}

$\operatorname{xxx}$

$\mathrm{xxx}$

\section{Pada saat penyerahan nasabah}

Pada saat nasabah menyerahkan barang atau menyampaikan bukti pembelian barang dan kemudian menyerahkan barang tersebut kepada nasabah, pencatatan akuntansi yang dikeluarkan oleh PSAK No.102, sebagai berikut :

Dr. Persediaan aset Murabahah

Cr. Piutang wakalah $\mathrm{xxx}$

XXX 


\section{Pada saat penjualan barang ke nasabah}

Pada saat penjualan barang oleh bank ke nasabah, Bank Syariat X melakukan jurnal:

Pencatatan akuntansi yang dikeluarkan oleh PSAK No.102

Dr. Piutang murabahah

Cr. Margin murabahah ditangguhkan

$\operatorname{xxx}$

Cr. Persediaan asset murabahah

$\mathrm{XXX}$

$\mathrm{XXX}$

Pada saat penerimaan Uang Muka (urbun) dari nasabah

Pencatatan akuntansi yang terdapat pada PSAK No. 102, atas penerimaan uang muka dari nasabah, adalah sebagai berikut:

Dr. Kas/rekening nasabah

$\mathrm{xxx}$

Cr. Hutang uang muka

$\operatorname{xxX}$

\section{Pada saat aktiva jadi dibeli oleh nasabah}

Pada saat terjadi akad murabahah dan aktiva murabahah jadi dibeli, pencatatan akuntansi yang dikeluarkan oleh PSAK No. 102 akan dicatat sebagai berikut:

Dr. Hutang Uang Muka

$\mathrm{XXX}$

Cr. Piutang murabahah

$\mathrm{XXX}$

\section{Pada saat penerimaan angsuran dari nasabah}

Pada saat penerimaan angsuran dari nasabah (pokok dan margin) menggunakan pengakuan pendapatan cash basis, yaitu pendapatan baru diakui pada saat kas benar-benar diterima, maka pembayaran angsuran pertama oleh nasabah yang diterima akan dicatat sebagai berikut:

Pencatatan akuntansi yang dikeluarkan oleh PSAK No. 102

Dr. kas/rekening nasabah

$\mathrm{XXX}$

Cr. piutang murabahah

$\mathrm{XXX}$

Dr. margin murabahah tangguhan

Cr pendapatan margin murabahah

$\mathrm{XXX}$

$\mathrm{XXX}$

\section{Penerimaan potongan pelunasan sebelum jatuh tempo} berikut:

Jika ingin melunasi hutang murabahahnya sebelum jatuh tempo dan akan dicatat sebagai

Pencatatan akuntansi yang dikeluarkan oleh PSAK No. 102

Dr kas/rekening nasabah

$\mathrm{XXX}$

Dr margin murabahah tangguhan

$\mathrm{XXX}$

Cr piutang murabahah

$\mathrm{XXX}$

Cr pendapatan margin murabahah

$\operatorname{XXX}$

Potongan angsuran sebesar margin selama 4 bulan kedepan dari margin yang belum jatuh tempo dan belum di terima tersebut diakui sebagai beban potongan (muqasah) oleh bank. 
Berdasarkan hasil analisis pada perbandingan penerapan akuntansi pada saat nasabah dikenakan denda murabahah telah sesuai dengan PSAK No. 102 paragraf 29 yaitu: Denda dikenakan jika pembeli lalai dalam melakukan kewajibanya sesuai dengan akad, dan denda yang diterima diakui sebagai bagian dana kebajikan.

\section{Penerimaan beban potongan pelunasan sebelum jatuh tempo}

Jurnal untuk beban potongan (muqasah)

Dr beban potongan

XXX

Cr kas/rekening nasabah

$\mathrm{XXX}$

\section{Pada saat nasabah dikenakan denda murabahah}

Apabila nasabah tidak dapat memenuhi kewajibannya sesuai dengan yang dijanjikan, bank berhak mengenakan denda kecuali jika nasabah dapat membuktikan bahwa nasabah tidak mampu melunasi. Maka dari itu, bank harus menunda penagihan hutang sampai nasabah mampu melunasinya. Besarnya denda sesuai dengan perjanjikan dalam akad dan dana yang berasal dari denda diperuntukkan sebagai dana sosial (qadrul hasan). Hal itu dicatat sebagai berikut:

Pencatatan akuntansi yang dikeluarkan oleh PSAK No. 102

Dr Kas/rekening nasabah

$\mathrm{XXX}$

Dr Rekening wadiah-dana kebajikan

$\mathrm{xxx}$

\section{Penyajian Laporan Keuangan Bank Syariat}

PSAK 102 (2008) paragraf 37-39, telah mengatur penyajian murabahah dalam laporan keuangan sebagai berikut: a) Piutang murabahah disajikan sebesar nilai bersih yang dapat direalisasikan, yaitu saldo piutang murabahah dikurangi penyisihan kerugian piutang. b) Margin murabahah tangguhan disajikan sebagai pengurang (contra account) piutang murabahah. Beban murabahah tangguhan disajikan sebagai pengurang (contra account) hutang murabahah.

Berdasarkan PSAK 102 tentang Akuntansi Murabahah Laba Rugi bank syariat adalah sebagai berikut:

Tabel 3 Laporan Laba Rugi

Periode 1 Januari s/d Desember 2010

\begin{tabular}{|c|c|c|}
\hline \multirow{2}{*}{\multicolumn{3}{|c|}{$\begin{array}{c}\text { Pendapatan Operasi Utama Bank Syariat } \\
\text { Pendapatan dari jual beli: }\end{array}$}} \\
\hline & & \\
\hline Murabahah & & $\mathrm{xxx}$ \\
\hline Ishtisna & & $\mathrm{xxx}$ \\
\hline Ishtisna & & $\mathrm{xxx}$ \\
\hline Salam & & $\mathbf{x x x}$ \\
\hline \multicolumn{3}{|l|}{ Pendapatan bagi hasil } \\
\hline Mudharabah & & $\mathrm{xxx}$ \\
\hline \multirow{2}{*}{ Musyarakah } & & $\mathrm{xxx}$ \\
\hline & & $\mathbf{x x x}$ \\
\hline Pendapatan dari sewa & & $\mathbf{x x x}$ \\
\hline Pendapatan operasi utama lainnya & $\mathbf{x x x}$ & \\
\hline Hak pihak ketiga atas bagi hasil ITT & & $\mathbf{x x x}$ \\
\hline Pendapatan operasional lainnya & & $\mathbf{x x x}$ \\
\hline
\end{tabular}




\begin{tabular}{lc}
\hline Beban operasi lainnya: & \\
Beban umum dan Administrasi (beban Muqasah) & xxx \\
Beban tenaga kerja & \\
Pendapatan non operasi & $\mathbf{x x x}$ \\
Beban non operasi & $(\mathrm{xxx})$ \\
\hline
\end{tabular}

Sumber: Yusuf dan Wiroso (2011: 235)

Berdasarkan PSAK 107, posisi neraca kolom aktiva adalah sebagai berikut.

Tabel 4 Neraca Bank Syariat X

Per 31 Desember 2010

\begin{tabular}{lcc}
\multicolumn{1}{c}{ Aktiva } & Pasiva \\
\hline Piutang murabahah & Rp XXX & \\
Margin murabahah tangguhan & (Rp XXX) \\
Piutang murabahah bersih & Rp XXX \\
\hline
\end{tabular}

Sumber: Yusuf dan Wiroso (2011: 19)

\section{Pengungkapan Pembiayaan Akuntansi Murabahah}

Pengungkapan transaksi murabahah berdasarkan PSAK 102 adalah sebagai berikut. Pertama, penjual mengungkapkan hal-hal yang terkait dengan transaksi murabahah, tetapi tidak terbatas pada: harga perolehan aset murabahah, janji pemesanan dalam murabahah berdasarkan pesanan sebagai kewajiban atau bukan, dan pengungkapan yang diperlukan sesuia PSAK 101: Penyajian Laporan Keuangan Syariat. Kedua, pembeli mengungkapkan hal-hal yang terkait dengan transaksi murabahah, tidak terbatas pada nilai tunai aset yang diperoleh dari transaksi murabahah, jangka waktu murabahah tangguh, dan pengungkapan yang diperlukan sesuai PSAK 101: Penyajian Laporan Keuangan Syariat.

\section{Penelitian Terdahulu}

Menurut Kusmiyati (2007) berdasarkan analisis yang telah dilaksanakan, terlihat bahwa sebagian besar konsep dan pelaksanaan pembiayaan murabahah pada ketiga BMT telah sesuai dengan prinsip-prinsip syariat, namun hal-hal yang dinilai belum memenuhi persyaratan akad murabahah yaitu dalam hal: 1) Penentuan akad menggunakan akad murabahah untuk pembiayaan tambah modal. Namun dalam perdagangan umum ada perputaran dana sehingga BMT dan anggota dapat berbagi hasil/keuntungan. 2) Pembelian barang; pembelian obyek atau barang murabahah dilakukan dengan cara mewakilkan kepada anggota.

Penelitian yang dilakukan oleh Oktavia (2010), menjelaskan bahwa pendapatan margin murabahah merupakan pendapatan dari transaksi normal dan bukan transaksi incidental. Pengakuan pendapatan yang dilakukan sudah sesuai dengan ketentuan PSAK No. 101 dan 102, baik dari metode yang dipakai untuk mengakui keuntungan maupun untuk pelaporan keuanganya. Namun, ada yang berbeda yaitu pada pembiayaan murabahah karena yang dibiayakan berupa uang atau berupa peminjaman kredit.

\section{METODE PENELITIAN}

\section{Kerangka Pemikiran}

Penelitian ini mengevaluasi tentang penerapan dan perlakuan akuntansi untuk transaksi murabahah berdasarkan PSAK 102 yang dilakukan di Bank Syariat X dan pembiayaannya hanya pada pembiayaan murabahah. Penelitian ini membandingkan antara pelaksanaan pencatatan, pengakuan 
serta pengukuran akuntansi murabahah yang dilakukan Bank Syariat X dibandingkan dengan PSAK 102 tentang akuntansi murabahah. Hasil akhir penelitian ini hanya bersifat evaluasi. Kerangka pemikiran tentang penerapan dan perlakuan akuntansi untuk transaksi murabahah berdasarkan PSAK 102 yang dilakukan di Bank Syariat X digambarkan sebagai berikut:

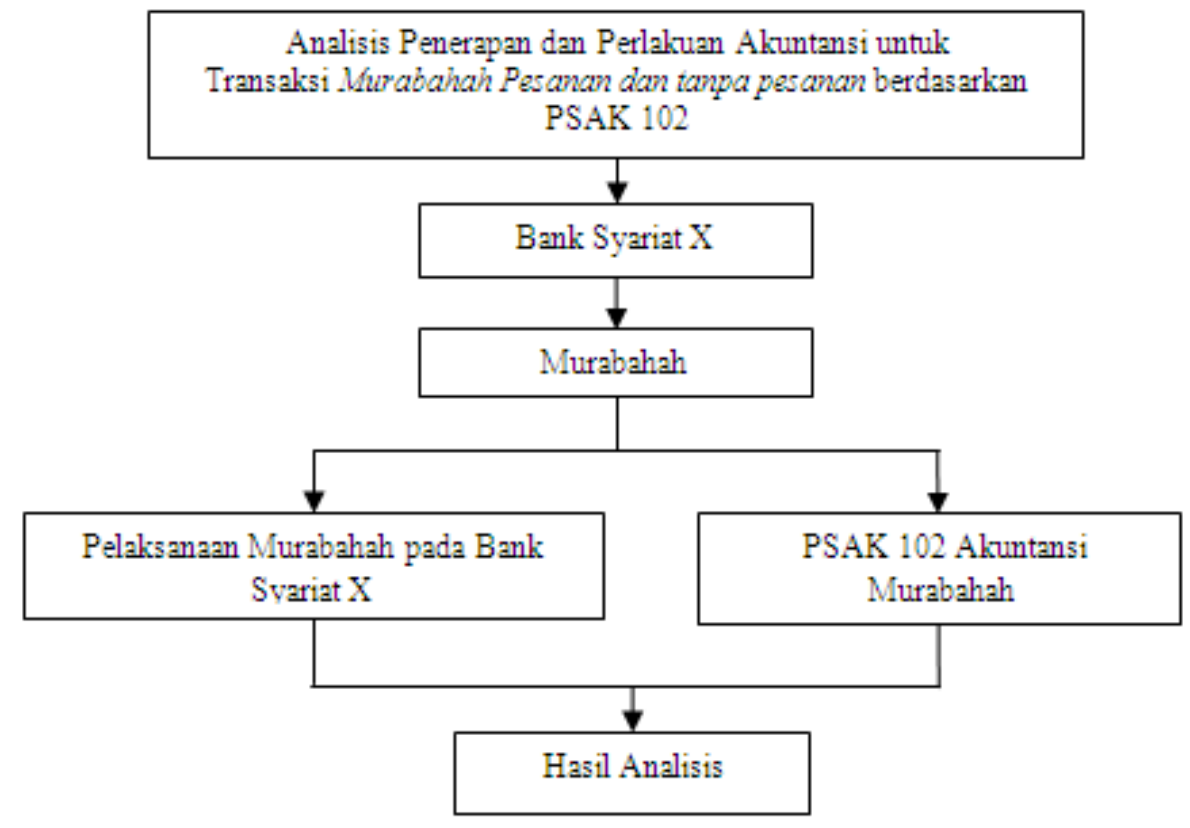

Gambar 1 Kerangka Pemikiran Sumber: Olah Data

\section{Metode Pengumpulan Data}

Metode pengumpulan data yang digunakan dalam memperoleh berbagai sumber informasi yang dibutuhkan dalam menyusun penelitian ini adalah sebagai berikut.

\section{Penelitian Kepustakaan}

Metode ini dilakukan dengan membaca dan mempelajari buku, artikel, serta jurnal terdahulu yang merupakan pendapat para ahli dan yang mempunyai relevansi dengan prosedur dan perlakuan akuntansi pembiayaan murabahah. Hal ini dimaksudkan untuk mendapatkan landasan teoritis sebagai dasar pemahaman dan perbandingan dengan pelaksanaan sesungguhnya di dalam perusahaan.

\section{Penelitian Lapangan}

Metode ini dilakukan dengan cara-cara sebagai berikut. Pertama, wawancara; penulis melakukan wawancara langsung dengan pimpinan Bank Syariat $\mathrm{X}$, kemudian dengan bagian administrasi, bagian pembukuan, dan bagian pemasaran. Kedua, observasi; pada tahap observasi ini, penulis mengamati langsung terhadap masalah yang diteliti pada sumber data yang dibahas sebatas perizinan perusahaan. Dalam hal ini penulis mempelajari dokumen yang ada dalam perusahan baik dalam bentuk formulir, laporan laba rugi, dan neraca Bank Syariat X. 


\section{Metode Analisis Data}

Metode analisis data yang digunakan dalam penelitian ini adalah dengan metode deskriptif analisis, yaitu penelitian dengan mengumpulkan data sesuai dengan keadaan sebenarnya, serta memberikan gambaran dan analisis mengenai masalah yang ada. Sedangkan penelitiannya dengan menggunakan pendekatan studi kasus, yaitu meneliti salah satu masalah yang ada dalam perusahaan.

\section{HASIL DAN PEMBAHASAN}

\section{Analisis Pelaksanaan Pembiayaan Murabahah pada Bank Syariat X}

Bank Syariat X menganut pembiayaan murabahah bil wakalah berdasarkan Fatwa Dewan Syariat Nasional No: 04/DSN-MUI/IV/2000, yaitu jika bank mewakilkan kepada nasabah untuk membeli barang dari pihak ketiga, akad jual beli murabahah harus dilakukan setelah barang, secara prinsip, menjadi milik bank. Selalu terjadi akad wakalah dulu sebelum akad murabahah karena akad wakalah akan berakhir pada saat nasabah menyerahkan barang yang dibeli pada bank dan mempercepat proses pencairan dan mempermudahkan nasabah, sehingga setelah barang diterima oleh bank maka terjadilah akad murabahah.

Piutang murabahah yang diakui sebesar biaya perolehan aset murabahah ditambah keuntungan yang disepakati, pada akhir periode laporan keuangan akan dinilai sebesar nilai bersih yang dapat direalisasi, yaitu saldo piutang dikurangi penyisihan kerugian piutang. Margin murabahah yang ditangguhkan disajikan sebagai pos lawan piutang murabahah. Diskon yang didapatkan dari pemasok akan dikurangkan ke harga jual karena diskon adalah hak nasabah. Pembayaran piutang murabahah dilakukan secara angsuran selama waktu yang disepakati namun pelunasan dapat dilakukan nasabah pada tengah-tengah angsuran atau pada akhir perjanjian, bank akan memberi potongan dengan syarat tidak diperjanjikan dalam akad.

Potongan pelunasan merupakan pengurang keuntungan murabahah yang akan ditanggung bank. Sebaliknya, apabila pembayaran angsuran terlambat, akan dikenakan denda atas kelalaian melakukan kewajiban sesuai dengan akad. Denda tersebut tentunya tidak memberatkan nasabah karena bertujuan untuk memberikan efek jera bagi nasabah agar diharapkan tidak terjadi kelalaian lagi. Denda diakui sebagai dana kebajikan, karena denda yang diperoleh bank akan disalurkan sebagai infaq sodaqoh. Pembayaran murabahah oleh nasabah dapat dilakukan secara angsuran selama jangka waktu yang disepakati, dengan memperhatikan kemampuan mengangsur ataupun arus kas usaha nasabah, besar angsuran yang telah disepakati tidak boleh berubah hingga akad pembiayaan berakhir.

Pengakuan untuk margin keuntungan, diskon, denda keterlambatan, dan potongan pelunasan piutang yang diterapkan Bank Syariat $X$ telah sesuai dengan PSAK No. 102. Cara pengakuan keuntungan murabahah terbagi menjadi tiga, yaitu pada saat penyerahan barang apabila tangguh lebih dari satu tahun dengan risiko penagihan kas dari piutang murabahah dan beban pengelolaan piutang serta penagihannya relatif kecil, secara proporsional apabila risiko piutang tidak tertagih relatif besar dan beban untuk menagih relatif besar juga. Pada saat seluruh piutang tertagih apabila risiko piutang tidak tertagih dan beban pengelolaan piutang serta penagihannya cukup besar hingga diragukan dan macet.

\section{Perlakuan Akuntansi Pembiayaan dengan Akad Murabahah pada Bank Syariat $\mathrm{X}$ dan Kesesuaian dengan PSAK 102}

Pada setiap perusahaan, tidak lepas dari proses pengakuan, pengukuran, penyajian dan pengungkapan atas suatu transaksi, begitu juga dengan transaksi Murabahah pada bank Syariat X. 
Mulai dari penentuan margin, penjurnalan setiap transaksi, penyajian pada laporan keuangan hingga pengungkapannya akan dijelaskan sebagai berikut.

\section{Penentuan Margin}

Dalam menentukan harga jual kepada nasabah Bank Syariat X, akan menetapkan margin terlebih dahulu yang telah disepakati. Metode perhitungan margin yang digunakan adalah metode margin keuntungan anuitas atau efektif yaitu sistem pembayaran yang dilakukan setiap selang waktu yang teratur dalam jumlah yang sama atau tetap, dengan nominal angsuran margin setiap periode atau bulan akan menurun, sedangkan angsuran pokok semakin meningkat.

Perhitungan jumlah angsuran, porsi margin, porsi pokok yang ada di Bank Syariat $\mathrm{X}$ telah terkomputerisasi dengan menggunakan software statistik. Berikut adalah contoh pembiayaan murabahah pada Bank Syariat X, terkait dengan kepemilikan kendaraan bermotor (KBB). Harga beli kendaraan adalah Rp 120.000.000,- dengan jangka waktu pembiayaan adalah 1 tahun dan margin keuntungan sebesar Rp 18.000.000,- (18\%) per tahun, telah dibayar uang muka sebesar Rp 20.000.000,-. Skim Pembiayaan: Murabahah Bil Wakalah, Nama Produk: Murabahah KKB iB, Tujuan Penggunaan: Pembelian Kendaraan Bermotor, Uang Muka: Rp 20.000.000,-. Pembiayaan Bank: Rp 100.000.000,- (harga beli-uang muka). Harga Jual: Rp 138.000.000,-. Jangka waktu: 24 bulan. Awal angsuran: 20 Jan 2010, akhir angsuran: 20 Des 2011. Denda Rp 1.000.000,-

Penghitungan margin murabahah:

a. Jumlah angsuran (lihat formula jumlah angsuran)

$$
=4.992 .410,20
$$

b. Jumlah porsi margin ( lihat formula porsi margin)

$\mathrm{AM}_{1}=100.000 .000 \times 0,15$

$$
=1.500 .000
$$

jumlah porsi margin yang pertama kali harus dibayar oleh nasabah adalah Rp 1.500 .000

c. Jumlah porsi pokok (lihat formula porsi pokok)

$$
\begin{aligned}
\mathrm{AP} 1 & =4.992 .410,20-1.500 .000 \\
& =3.492 .410,20
\end{aligned}
$$

Jadi, jumlah porsi pokok yang harus dibayar oleh nasabah adalah Rp 3.492.410,20.

\section{Pencatatan Ayat Jurnal Transaksi Murabahah}

Bank Syariat X menggunakan PSAK sebagai acuan akuntansi untuk transaksi syariat, salah satunya PSAK No. 102 tentang Akuntansi Murabahah yang digunakan sebagai dasar dari pembiayaan murabahah. Pada praktik Murabahah, Bank Syariat X mewakilkan kepada nasabah pembeli untuk membeli barang yang dipesankan atas nama Bank Syariat X dengan uang muka yang telah diserahkan nasabah kepada supplier adalah sebesar Rp 20.000.000, sehingga Bank Syariat X menyerahkan uang tunai kepada nasabah sebesar Rp 100.000 .000 yang semula harga perolehan barang sebesar Rp 120.000.000. Dengan demikian, pencatatan transaksi piutang murabahah sebagai berikut.

Pada saat memberi kuasa ke nasabah; Bank Syariat X memberi kuasa kepada nasabah untuk membeli barang, maka hal ini dibukukan dalam perkiraan piutang wakalah sebesar uang yang diserahkan kepada nasabah, pencatatan akuntansi yang dikeluarkan oleh Bank Syariat X, sebagai berikut.

Dr Piutang wakalah

Cr Rekening nasabah-pembeli
Rp. 100.000.000,-

Rp. 100.000.000,- 
Berdasarkan hasil analisis perbandingan pada proses pemberian kuasa antara PSAK No. 102 dengan pencatatan yang dilakukan oleh Bank Syariat telah sesuai.

Pada saat nasabah menyerahkan barang atau menyampaikan bukti pembelian barang (barang ditempat nasabah) dan kemudian menyerahkan barang tersebut kepada nasabah, maka Bank Syariat X, melakukan pencatatan transaksi sebagai berikut.

$$
\begin{aligned}
& \text { Dr Persediaan / Aset Murabahah } \quad \text { Rp. 100.000.000,- } \\
& \text { Cr Piutang wakalah }
\end{aligned}
$$

$$
\text { Rp.100.000.000,- }
$$

Pada saat Bank Syariat menjual barang ke nasabah, berdasarkan hasil analisis pada penerapan akuntansi saat penyerahan barang atau bukti pembelian, pencatatan akuntansi yang dilakukan oleh Bank Syariat, sebagai berikut.

\section{Dr Piutang murabahah \\ Cr Persediaan \\ Cr Margin murabahah}

Rp. 118.000.000,-

$$
\begin{aligned}
& \text { Rp. 100.000.000,- } \\
& \text { Rp. 18.000.000,- }
\end{aligned}
$$

Berdasarkan hasil analisis pada penerapan akuntansi saat pelaksanaan akad murabahah telah sesuai dengan PSAK No. 102. Pada saat akad murabahah, piutang murabahah diakui sebesar biaya perolehan aset murabahah ditambah keuntungan yang disepakati.

Untuk pembiayaan KKB diharuskan untuk membayar uang muka sebesar yang telah ditentukan oleh supplier. Pada saat nasabah membayar uang muka, maka bank akan mencatat: Pencatatan Akuntansi yang dilakukan oleh Bank Syariat X, sebagai berikut.

Dr Kas/rekening-nasabah

Cr Hutang uang muka
Rp 20.000.000,-

$$
\text { Rp 20.000.000,- }
$$

Pengakuan uang muka murabahah juga telah sesuai dengan PSAK No. 102. Dalam hal ini, uang muka murabahah (urbun) diakui sebagai uang muka pembelian sebesar jumlah yang diterima.

Pada saat terjadi akad murabahah dan aktiva murabahah jadi dibeli, pencatatan akuntansi yang dilakukan oleh Bank Syariat X, dicatat sebagai berikut.

Dr Hutang uang muka
Cr Piutang murabahah
Rp 20.000.000,-

$$
\text { Rp 20.000.000,- }
$$

Berdasarkan hasil analisis pada penerapan akuntansi saat aktiva murabahah jadi dibeli telah sesuai dengan PSAK No. 102. Dimana uang muka diakui sebagai pembayaran piutang tidak sebagai pembayar angsuran.

Pada saat penerimaan angsuran dari nasabah (pokok dan margin), Bank Syariat $\mathrm{X}$ menggunakan pengakuan pendapatan cash basis, yaitu pendapatan baru diakui pada saat kas benarbenar diterima, maka pembayaran angsuran pertama oleh nasabah yang diterima akan dicatat, pencatatan akuntansi yang dikeluarkan oleh Bank Syariat X sebagai berikut.

Dr Kas

Cr Piutang murabahah

Dr Margin murabahah tangguhan

Cr Pendapatan margin murabahah
Rp 4.992.410,20

Rp 4.992.410,20

Rp 1.500.000
Rp 1.500.000 
Hasil analisis perbandingan pada Penerapan akuntansi saat membayar angsuran telah sesuai dengan PSAK 102.

Penerimaan potongan pelunasan sebelum jatuh tempo, nasabah melunasi angsuran murabahah pada angsuran ke-20. Bank akan memberikan potongan pelunasan yang disebut muqasah sebesar margin selama 4 bulan kedepan. Dalam catatan Bank Syariat X sebagai berikut: Sisa angsuran : Rp 24.962.050,98- Sisa margin 4 bulan : Rp 1.085.125,45-. Muqasah : Rp 1.085.125,45-. Pelunasannya : Rp 24.962.050,98 (sisa angsuran) - Rp 1.085.125,45 (sisa margin) $=\mathrm{Rp} 23.876 .925,53,-$. Dari perhitungan tersebut, nasabah harus membayar sebesar Rp 23.876.925,53. Pencatatan akuntansi yang dikeluarkan oleh Bank Syariat X

Dr Kas

Dr Margin murabahah tangguhan

Cr Piutang murabahah

Cr Pendapatan margin murabahah

Jurnal untuk beban potongan (muqasah)

Dr Beban potongan

Cr Kas/rekening nasabah
Rp 23.876.925,53

Rp 1.085.125,45

Rp 23.876.925,53

Rp 1.085.125,45

Rp 1.085.125,45

Berdasarkan hasil analisis pada perbandingan penerapan akuntansi pada bank, diterima pelunasan angsuran yang tertunggak dan bank memberikan potongan sebesar margin selama 4 bulan ke depan dari margin jatuh tempo yang belum diterima telah sesuai dengan PSAK No. 102. Potongan angsuran sebesar margin selama 4 bulan kedepan dari margin yang belum jatuh tempo dan belum di terima tersebut diakui sebagai beban potongan (muqasah) oleh bank.

Pada saat nasabah dikenakan denda murabahah, besarnya denda sesuai dengan yang diperjanjikan dalam akad dan dana yang berasal dari denda diperuntukkan sebagai dana sosial (qadrul hasan). Maka, dicatat sebagai berikut.

Pencatatan akuntansi yang dikeluarkan oleh Bank Syariat X

Dr Kas/ rekening nasabah

Cr Rekening ZIS

Rp1.000.000

Rp $\quad 1.000 .000$

\section{Penyajian Laporan Keuangan Bank Syariat X}

Penyajian pembiayaan murabahah dalam laporan laba rugi dan neraca Bank Syariat X, adalah sebagai berikut (berdasarkan dengan contoh kasus yang ada sampai dengan tanggal 31 Desember 2010): Bank Syariat X akan mengakui pendapatan yang berasal dari pendapatan margin murabahah sebesar Rp 14.363.662,58, yaitu keuntungan selama 1 tahun pertama (tahun 2010); Piutang murabahah akan bersaldo Rp 58.091.077,64 berasal dari : Rp 138.000.000 - Rp 20.000.000 - Rp 59.908.922,36. Keterangan: Rp 20.000.000,- adalah pembayaran pertama nasabah (uang muka) dan Rp 59.908.922,36 adalah pembayaran selama 1 tahun; Margin murabahah tangguhan akan bersaldo Rp 3.636.337,42,- berasal dari : Rp 18.000.000 - Rp 14.363.662,58 (yang telah diakui tahun 2010) ; rekening ini disajikan sebagai pos lawan piutang murabahah. Laporan neraca Bank Syariat $\mathrm{X}$ disajikan sebagai berikut. 
Tabel 5 Neraca Bank Syariat X

Per 31 Desember 2010

\begin{tabular}{lc}
\hline \multicolumn{1}{c}{ Pos-Pos } & Posisi 31 Desember 2010 \\
\hline AKTIVA & \\
Piutang iB Murabahah & Rp58.091.077,64 \\
Margin murabahah tangguhan & $\frac{(\mathrm{Rp} 58.091 .077,64)}{\mathrm{Rp} 54.454 .740,22}$ \\
Piutang i & \\
B murabahah bersih & $\mathrm{Rp54.454.740,22}$ \\
JUMLAH & \\
\hline
\end{tabular}

Sumber: Bank Syariat X

Sedangkan laporan Laba Rugi Bank Syariat X digambarkan sebagai berikut.

Tabel 6 Perhitungan Laba Rugi Publikasi Bank Syariat X Periode Desember 2010

\begin{tabular}{lc}
\hline \multicolumn{1}{c}{ POS-POS } & Posisi Des 2010 \\
\hline A PENDAPATAN OPERASIONAL & \\
1 Margin & $\mathbf{1 4 . 3 6 3 . 6 6 2 , 5 8}$ \\
2 Bagi hasil & $\mathrm{xxxx}$ \\
3 Bonus & $\mathrm{xxxx}$ \\
4 Pendapatan Operasional Lainnya & $\mathrm{xxxx}$ \\
B JUMLAH PENDAPATAN OPERASIONAL & $\mathbf{x x x x}$ \\
\hline
\end{tabular}

Sumber: Bank Syariat X

Berdasarkan hasil analisis, dalam penyajian pada Bank Syariat X telah sesuai dengan PSAK 102 tentang Akuntansi Murabahah karena pada Bank Syariat X piutang murabahah disajikan secara neto yaitu dikurangi margin murabahah tangguhan.

\section{Pengungkapan Pembiayaan Murabahah pada Bank Syariat X}

Pengungkapan transaksi murabahah Bank Syariat X mencakup: harga perolehan aset murabahah senilai Rp 120.000.000; janji pemesanan dalam murabahah berdasarkan pesanan sebagai kewajiban atau bukan; dan pengungkapan yang diperlukan sesuai PSAK 101 adalah penyajian Laporan Keuangan Syariat.

Berdasarkan hasil analisis dalam pengungkapan, Bank Syariat X belum sesuai dengan PSAK 102 tentang Akuntansi murabahah, karena Bank Syariat X tidak mengungkapkan dari sisi pembeli tetapi hanya melakukan pengungkapan dari sisi penjual saja.

\section{SIMPULAN}

Berdasarkan hasil penelitian dan pembahasan, dapat ditarik simpulan sebagai berikut. Pertama, setiap nasabah yang ingin mendapatkan pembiayaan di bank syariat, harus mengikuti prosedur pembiayaan yang berlaku berdasarkan prinsip syariat. Kedua, Bank Syariah X, dalam melaksanakan pembiayaan murabahah, hanya menerapkan murabahah berdasarkan pesanan saja. Sedangkan pada PSAK No. 102, murabahah dapat dilakukan berdasarkan pesanan atau tanpa pesanan. Ketiga, dalam pengimplementasian PSAK No.102 mengenai Akuntansi Murabahah dan hasil analisis, 
disimpulkan bahwa Bank Syariat X belum sepenuhnya menerapkan PSAK No.102 tentang Akuntansi Murabahah. Bank Syariat X hanya menjelaskan tentang pengakuan dan pengukuran murabahah dari perspektif penjual saja. Sedangkan dalam PSAK No.102, harus pula dijelaskan ketentuan pengakuan dan pengukuran murabahah dari perspektif penjual, dan dari perspektif pembeli.

\section{Saran}

Adapun saran yang diajukan, yang dapat menjadi bahan pertimbangan bagi Bank Syariat X, adalah sebagai berikut. Pertama, dalam pengimplementasian PSAK No. 102 mengenai akuntansi Murabahah, khususnya dalam pengakuan dan pengukurannya, tidak hanya dari perspektif penjual saja tetapi juga dari perspektif pembeli, sebagaimana yang telah diatur dalam PSAK No. 102. Kedua, dalam perkembangan Bank Syariat X, hendaknya dapat mengembangkan dan meningkatkan kualitas pembiayaan, khususnya pada pembiayaan murabahah, bukan hanya pada produk kredit pembiayaan bermotor saja, tetapi dengan diversifikasi produk lainnya, seperti perumahan dan kebutuhan rumah tangga, sehingga dapat menarik nasabah untuk pembiayaan murabahah yang sesuai dengan prinsip syariat. Dan ketiga, diharapkan peneliti selanjutnya dapat lebih meneliti jenis pembiayaan lainnya, yang terkait dalam proses pembiayaan produk jual beli agar lebih banyak variabel yang akan dipelajari seperti produk salam dan istishna.

\section{DAFTAR PUSTAKA}

Departemen Agama Republik Indonesia. (2005). Al-Quran dan terjemahannya. Jakarta: Balai Pustaka.

Fatwa DSN : No.04/DSN-MUI/IV/2000, Murabahah bil Wakalah, Jakarta: MUI.

Harahap, S. S., Wiroso, dan Yusuf, M. (2010). Akuntansi Perbankan Syariah. Jakarta: LPFE Usakti.

Kusmiyati. (2007). Resiko akad dalam pembiayaan murabahah pada BMT di Yogyakarta, Jurnal Ekonomi Islam la-Riba Vo.1. No.1. juli 2007,UII Press.

Nurhayati, Sri, dan Wasilah. (2010). Akuntansi Syariah di Indonesia. Jakarta: Salemba Empat.

Oktavia. (2010). Penerapan PSAK 102 pada perlakuan akuntansi pengakuan pendapatan untuk pembiayaan Murabahah pada koperasi syariah, skripsi- STIE Perbanas-Surabaya.

PSAK IAI. (2008). Pernyataan Standar Akuntansi Keuangan Nomor 102. Jakarta: IAI.

Rivai, V., \& Arifin, A. (2008). Islamic Banking. Jakarta: Bumi Aksara.

Undang-Undang Perbankan, UU no.10/1998 tentang tentang Prinsip perbankan Syariah, Jakarta: Sinar Grafika.

Undang-Undang Perbankan, UU no.21/2008 tentang tentang perbankan Syariah, Jakarta: Sinar Grafika.

Yusuf \& Wiroso. (2011). Bisnis Syariah. Jakarta: Mitra Wacana. 